Article

\title{
Energy Security in Turbulent Times Towards the European Green Deal
}

\author{
Odysseas Christou \\ Department of Law, University of Nicosia, Cyprus; E-Mail: christou.o@unic.ac.cy
}

Submitted: 1 April 2021 | Accepted: 6 August 2021 | Published: 30 September 2021

\begin{abstract}
This article presents a theoretical approach to energy security. It incorporates the concept of governing through turbulence as both a response to crisis onset and a source of long-term policy adaptation. The article applies this framework to an empirical analysis of the energy and climate policy of the EU through a review of policy documents in the period between 1995 and 2020. The article presents the evolution in the conceptualization of energy security in EU policy from a narrow definition restricted to characteristics of energy supply to an expanded conception that integrates additional elements from associated policy areas. The article argues that the European Green Deal represents the culmination of this process and concludes that the convergence of energy and climate policy objectives reinforces the trend towards the widened conceptual scope of energy security.
\end{abstract}

\section{Keywords}

energy; Energy Union; European Green Deal; governance; policy; security; turbulence

\section{Issue}

This article is part of the issue "Climate Governance and the European Green Deal in Turbulent Times" edited by Claire Dupont (Ghent University, Belgium) and Diarmuid Torney (Dublin City University, Ireland).

(C) 2021 by the author; licensee Cogitatio (Lisbon, Portugal). This article is licensed under a Creative Commons Attribution 4.0 International License (CC BY).

\section{Introduction}

International relations approaches overemphasize issues of geopolitical concern in energy relations with a distinct focus on security of supply. Goldthau and Witte (2010, p. 2) stress that this erroneously assumes a zero-sum game between states' energy security. They identify two key determinants of energy policy missing from the debate: the impact of energy markets on demand and supply patterns, and the impact of the national and international rules that govern them. This article emphasizes the second of these factors, albeit with a narrower focus. In the case of EU member states, the boundary of available policy options is ultimately determined by collective policy objectives and priorities that are centrally mandated at the EU level. Long-term policy enactments shift priorities that reorder policy options through the agenda-setting power of supranational institutions. When policy pronouncements become legislative enactments, then these policy objectives are transformed into legally binding targets for states and advance the role of the EU as an independent actor in the international energy market (Goldthau \& Witte, 2015, p. 941). On the other hand, legal approaches to the topic tend to underemphasize the geopolitical aspects of the debate and the pressure that they exert on states, thereby shaping their policy options.

This article adopts a theoretical approach to address the research question of how the concept of energy security has been implemented in the evolution of EU energy and climate policy. It presents the issues that arise out of the multiplicity of approaches in defining energy security. Furthermore, the article integrates the concept of turbulence to investigate whether EU policymaking can be characterized as crisis response or long-term adaptation. The article applies this framework to a review of EU energy and climate policy documents. It traces the evolving conceptual framing of energy security through a longitudinal review from 1995 to 2020 and places the four successive Energy Packages within the context of this evolution.

\section{Defining Energy Security}

Traditional conceptions of energy security have delimited its scope to the ability of states to maintain 
uninterrupted energy supply relative to demand at affordable and relatively stable prices. The International Energy Agency (2021), for example, defines energy security as the uninterrupted availability of energy sources at an affordable price. Energy insecurity, therefore, can arise out of either the interruption of energy supply or sudden price fluctuations that could render supply unaffordable. Chester (2010) identifies two dominant characteristics: (1) a narrow focus on security of supply of oil and gas as the two primary sources of energy, and (2) an application of this conceptualization of energy security in terms of geopolitical and foreign policy decision-making considerations. These are perhaps most compatible with the influential formulation of the four As of energy security (Asia Pacific Energy Research Centre, 2007): Availability of energy resources, Accessibility, Acceptability of associated environmental effects, and Affordability of investment. Cherp and Jewell (2014) problematize the four As approach by applying the logic of fundamental security questions: security for whom, for which values, and from what threats? They conclude that energy security conceptualizations that provide answers to these questions help to explain and inform policy options. Of the three, the first is of primary importance to this account, as it deals with the issue of specifying the object of energy security relations as discussed further below.

Other approaches have expanded the security of supply debate to the electricity sector as well (Hawker et al., 2017; Moore, 2017). More recent attempts, especially from outside international relations theories, have yielded various multi-faceted perspectives on defining energy security, revealing a consensus on the difficulties inherent in such definition-building. Ang et al.'s (2015) extensive meta-study of energy security approaches ultimately concludes that no widely accepted definition of energy security as a narrowly defined construct exists. They conclude that seven dominant themes have emerged: securing energy availability, securing energy infrastructure, securing the affordability of energy supplies (Bielecki, 2002), societal aims such as the eradication of energy poverty (Lesbirel, 2004), environmental security and sustainability (Pasqualetti \& Sovacool, 2012), energy security governance (Goldthau \& Sovacool, 2012), and the improvement of energy efficiency (Hughes, 2009; Kemmler \& Spreng, 2007). von Hippel et al. (2011) called for the establishment of a much more comprehensive conceptualization of energy security, where security of supply is one of many pillars that also includes economic, technological, environmental, social-cultural, and military-security dimensions. Vivoda (2010) further widens this conceptualization by including the three additional challenges of human security, international implications, and state capacity to implement specific energy security policies, while more recent approaches have made the explicit linkage between energy security and sustainability (Narula, 2019; Radovanović et al., 2017).
In the theoretical literature of security studies, energy security remains a largely underexplored area with some notable exceptions (Kirchner \& Berk, 2010; McGowan, 2011). According to Buzan et al. (1998, p. 116), the relative abundance of energy as a tradable commodity means that energy insecurity that may arise as an economic threat to stability does not pose a threat extending beyond the economic sector. Contrary to this position, this article argues that the extent to which energy can present risks depends on its conceptual framing as energy security could be subsumed in political, societal, and military discursive practices. It is also highly technical, particularly regarding environmental effects. As a result, energy can be theoretically examined as part of a widened security agenda (Natorski \& Herranz-Surralles, 2008). The inherent characteristics of energy security-namely that the impact of energy insecurity could be both imminent and immediate-are important factors for security (Christou \& Adamides, 2013). Imminence refers to the fact that energy insecurity can occur at any time and easily escalate from minor to existential threat. This escalation is likely to result from factors beyond economic considerations; indeed, political, and military factors only tangentially relevant to energy frequently lead to energy insecurity. Energy insecurity is also unique because of the immediate and severe impact it can have on the functioning of a state. As Ciuta (2010) asserts, the ubiquity of energy in distinct security logics drives the necessity for conceptual variation in a contextual perspective. Winzer (2012) proposed a set of conceptual boundaries to differentiate between security, sustainability, and economic efficiency by reformulating energy security to energy supply continuity. I integrate this reformulation to the narrow definition of energy security used in this article. This conceptual move helps clarify the definitional vagueness of energy security identified above and is applied to the operationalization described further below.

\section{Energy Security in the Context of Turbulence}

My conceptualization of turbulence uses Ansell et al.'s (2016, p. 2) definition of "interactions of events or demands that are highly variable, inconsistent, unexpected or unpredictable." Applying this concept to the narrow definition of energy security presented above with its emphasis on uninterrupted supply and affordability, this formulation suggests that turbulence may be equated with energy insecurity and, by extension, the possibility of crisis onset. Yet, Dobbs et al. (2021) differentiate turbulence from both uncertainty and crisis, even though they share clear conceptual linkages. Instead, they propose that both uncertainty and crises can be the outcomes of turbulent interactions. That is especially the case from an ontological perspective on energy security, whereby the emergence of insecurity is typically characterized by the defining attributes of a crisis (Boin et al., 2005, pp. 3-4): threat, urgency, and 
uncertainty. Conversely, it is unlikely that energy insecurity would be the result of deliberate policy shifts.

However, turbulence can also be conceptualized as a transformative process that results in fundamental shifts to the policy framework leading to long-term adaptation and change rather than the short-term abruptness that characterizes crises that arise in times of uncertainty (Ansell, 2016, p. 77). In other words, while instances of energy insecurity can be understood as crises, turbulence in energy policy need not produce crisis. In fact, quite to the contrary, turbulence framed as long-term adaptation towards specific policy objectives can foster the facilitating conditions towards the neutralization of crises. According to Dobbs et al. (2021), governing against turbulence takes the form of crisis response and management in the short run. But governing with turbulence requires long-term governance adjustments towards flexible, dynamic, and resilient policy outputs. Perhaps the best example to illustrate the distinction in terms of the direction of EU energy policy has been the centrality of EU-Russian energy relations. Each instance in the series of gas disputes between Russia and Ukraine since 2005 can be characterized as a crisis. Each entailed specific consequences for EU policymaking and each elicited specific crisis management responses. But the shifts in EU policy to anticipate and obviate crisis recurrence cannot be characterized in the same way. Instead, they represent the identification of persistent patterns of crisis onset and their counteraction through long-term adaptation.

Ansell and Trondal (2018) have introduced a typology of turbulence by distinguishing between turbulent environments, turbulent organizations, and turbulence of scale. They conclude that policymakers can confront turbulence by attempting to stabilize it, by adapting to it or by attempting a combination of the two strategies. They suggest that stabilization leads to path dependence and a static resilience that reinforces the status quo, while adaptation favors institutional change leading to a strategy of dynamic resilience that aims at continuous adaptation in the face of turbulence. Path dependence refers to cycles of reinforcing pressures and patterns of interaction whereby governance systems revert to preexisting organizational arrangements. This may result either because these arrangements are well-known and entrenched (Olsen, 2010, p. 96), because they present the potential for increasing returns (Pierson, 2000), or more generally because they favor specific reproduction mechanisms that define the scope for institutional evolution (Thelen, 1999).

\section{Operationalizing the Framework}

The main contribution of this article to the theoretical literature is an understanding of the conditions under which energy is embedded in security processes. In other words, an understating of how energy threats may escalate or-perhaps more importantly-de-escalate. This understanding depends largely on the definition of energy security that is employed. As described above, the traditional usage of the concept restricted the scope to elements of access, affordability, infrastructure, and economic cost. As a result, similarly to Winzer's (2012, p. 37) reconceptualization of energy security to energy supply continuity, one may conclude that the actual object in these approaches is not energy as a general term but energy supply. I apply the conceptual framework to a textual discursive analysis that examines the usage of energy security in EU policy statements. I survey all official policy documents that include explicit definitions of energy security from 1995 to 2020 covering developments starting from the formulation of an EU energy policy in 1995 and the First Energy Package in 1996 through the publication of the European Green Deal (EGD). I survey all formulations of energy security in the intervening years, including the succession of energy packages. While I focus on energy policy formulation, I include the introduction and development of climate policy objectives for the milestones of 2020, 2030, and 2050, as the energy-climate policy nexus becomes increasingly interdependent, and their policy objectives directly interlinked.

In so doing, I aim to examine two fundamental research questions with respect to the concepts of energy security and turbulence described above. The first question is: Does the definition of energy security in EU policy adhere to a traditional formulation that is narrowly restricted to supply characteristics, or does it integrate elements of the conceptual expansion of energy security? And if so, which elements are incorporated in this conceptual evolution? Additionally, I examine whether the definition of energy security conforms to stated policy objectives of energy policy imperatives, such as the nature of external relations, and dependency on energy resource types and actors. The second question is: Can we characterize the evolution of EU energy policy as governing against or with turbulence? Additionally, are we witnessing policy options being implemented to stabilize turbulence (path dependence) or to adapt to it (institutional change)? A corollary to this question concerns the EGD more specifically: Is the EGD another step in a path-dependent process or does it represent a shift in institutional configuration?

\section{The Evolving Conceptualization of Energy Security in EU Energy and Climate Policy}

This section traces the evolving conceptual framing of energy security through a longitudinal review of EU energy and climate policy pronouncements. It places the four successive Energy Packages within the context of this evolution. The analysis covers the period starting from the White Paper on EU Energy Policy of 1995 immediately preceding the First Energy Package through the Third Report on the State of the Energy Union of 2017 that followed the Fourth and latest Energy Package of 
2016. It ends with a discussion of the EGD and associated developments up to 2020 .

\subsection{Energy Security in the First and Second Energy Packages}

The policy trajectory of the Energy Packages begins with the White Paper (European Commission, 1995) establishing common aims for an EU energy policy. These are established in the context of a broader framework of global trends such as increasing market globalization, environmental and technological concerns, and institutional responsibilities. Economic competitiveness and security of supply are set as the main policy aims, while considering social and regional dimensions, as well as environmental protection policy priorities. The usage of energy security reveals an interesting dualism in terms of its adherence to traditional characteristics on the one hand, and conceptual expansion on the other. While the term is never explicitly defined, its major element is clearly the emphasis on security of supply. This is also exemplified in the Work Programme, which sets out crisis measures, diversification, and international relations' development as indicative actions for supply security management. However, even at this early stage in the development of EU energy policy, the contribution of additional policy priorities to energy security is acknowledged, such as the use of renewables and the prioritization of efficiency in energy use. The First Energy Package of 1996 focused on the integration of national energy markets into a unified, comprehensive market that is both harmonized and liberalized with primary application to the two major internal sub-components of electricity and gas. Conceptions of energy securitywhile significant determinants of the specificities of the measures adopted-were not expressed as central policy objectives. Instead, the measures focused on the removal of trade barriers, the harmonization of tax and pricing policies and measures, the integration of energy regulations with environmental and safety regulations, and ultimately the creation of free and fair access to a functioning market with adequate levels of consumer protection, interconnection, and generation capacity.

The approach of the 1995 White Paper remained unaltered in the European Commission's (1997) review of energy policy and actions, while the emphasis on availability was strengthened in the communication (European Commission, 2000a) on the EU's oil supply that looked forward to the Green Paper on a comprehensive energy security strategy. The Green Paper (European Commission, 2000b) represented a turning point by adopting a wider framing of energy security. It painted a stark picture of existing policy options and market conditions; for example, it characterized the EU's energy supply as "Gulliver in chains" and the external dependence on oil supply as being held hostage. It also identified the potential of renewables not only as an alternative but as a political priority. It concluded that the dearth of supply- side options necessitated shifting priorities towards managing demand. The necessity for this demand-driven approach was reinforced in the Final Report on the Green Paper (European Commission, 2002) and was carried over in the European Commission's (2003) communication on energy infrastructure and security of supply in the lead-up to the Second Energy Package. The communication established key policy objectives and necessary measures for the electricity and gas markets. The fundamental logic of the package was evolutionary from the first one and did not alter the principles and actions described above. The main regulatory innovation of the second package was the emphasis on the liberalization of competition, giving the ability to industrial and domestic consumers to choose among gas and electricity suppliers. All references to security in both the communication and the energy package concern supply, infrastructure, technical characteristics, and system reliability capacity.

\subsection{Energy Security in the Third and Fourth Energy Packages}

2007 represented the most significant turning point juncture in the evolution of EU energy policy, including in terms of the specification of energy security, in two fundamental ways (McGowan, 2011, p. 503). The first was the onset of the Russo-Ukrainian gas dispute in 2005 culminating in the disruption of supply to EU member states in early 2006. The crisis illustrated many of the risks identified in EU energy security priorities to that point: an imminent danger creating immediate and widespread disruption, a lingering volatile geopolitical environment that could lead to further incidents-as indeed evidenced on numerous occasions in the years since-and a lack of viable short-term alternatives. The conceptualization of energy security now placed at the center of the EU's approach was further established through the Strategic Energy Review on an energy policy for Europe (European Commission, 2007). It identified the following four pillars of insecurity: vulnerability concerning imports, shortfalls in supply, possible energy crises, and uncertainty with respect to future supply. The second major development was the expression of the energyclimate policy nexus as a vital strategic component for the first time. The review incorporated the specific objective of a $20 \%$ reduction of greenhouse gases by 2020 in comparison to 1990 reference levels. This formed the basis of the 2020 Climate and Energy Package in combination with the targets of a $20 \%$ share of renewable energies and a saving of $20 \%$ through energy efficiency in EU energy consumption by 2020 (European Commission, 2008a). The Second Strategic Energy Review (European Commission, 2008b) made the conceptual expansion of energy security explicit. Previous specifications of energy security priorities never explicitly defined its parameters, but rather analyzed individual characteristics as presented above. The new EU Energy Security and Solidarity Action Plan specified these parameters as: infrastructure 
needs and the diversification of energy supplies, external energy relations, oil and gas stocks and crisis response mechanisms, energy efficiency, and making the best use of the EU's indigenous energy resources. Thereafter, energy efficiency and its associated measures would not be considered merely ancillary or compatible with energy security priorities but an integral component of its conceptual scope.

The convergence would be inherent in the upcoming Third Energy Package of September 2009 that accelerated the integration processes of the first two packages without being restricted to the primary goal of market liberalization. Instead, it expanded the scope of application to create additional synergies between the regulatory implementation of energy and adjacent areas with environmental regulation and competition being foremost among them. In addition to new Directives on the common rules for the internal electricity and gas markets, the Package introduced new Regulations on the conditions for access to the network for crossborder exchanges in electricity and to the natural gas transmission networks. The Regulation for the establishment of the Agency for the Cooperation of Energy Regulators established new procedural arrangements with far-reaching consequences for the decision-making power of all stakeholders (Labelle, 2017). Effectively, the measures of the new package shifted the emphasis of this amended regulatory framework towards the options of ownership unbundling, the separation of energy supply and generation from the operation of transmission networks, and the establishment of Independent Transmission Operators and Independent System Operators, all under the regulatory supervision of independent National Energy Regulatory Authorities (De Somer, 2012). The Package led to subsequent measures more specific to the issue of energy security, such as the obligation on member states to maintain minimum stocks of oil products and measures to safeguard the security of gas supply, largely in response to the Russian-Ukrainian gas crisis during the winter of 2008-2009 (de Jong et al., 2012).

The update to the EU's energy strategy (European Commission, 2010) was largely a response to the concern that the 2020 targets would not be achieved. It aimed at consolidating the different policy objectives of the past decade into a comprehensive policy agenda and outlined five priorities: energy efficiency, energy market integration, consumer empowerment, technological innovation, and strengthening external dimensions. All pillars of this cohesive approach were reformulations of existing objectives except for the focus on consumer behavior. This was largely driven by the measures introduced in the Third Energy Package, since more open, competitive, and integrated energy markets must be accompanied by initiatives on consumer awareness and access. References to energy security adhere to established principles of infrastructure, supply, as well as the interrelation to efficiency targets. The strategy does not alter that conceptual scope since the strategy comes immediately after the Lisbon Treaty. Article 194 of the Treaty on the Functioning of the European Union established the major objectives of EU energy policy as market functionality, energy supply security, efficiency, and network interconnection. With these priorities enshrined in primary EU law, they form the legal basis for all subsequent legislative developments in this area.

In the years between the Third and Fourth Energy Packages, there was no major shift in the conceptualization of energy security. The major determinant of policy trajectory was the steady prioritization of climate policy objectives on the basis of the already expanded conceptual scope. Thus, two approaches can be observed. In policy pronouncements regarding energy security in the context of external relations, the traditional emphasis is maintained. For example, the EU energy policy on international cooperation (European Commission, 2011b) and the report on the progress towards completing the Internal Energy Market (European Commission, 2014d) both maintain focus on security of supply. In new policy initiativesthat typically centered on the increasing ambition of climate objectives-the widened scope was brought to the fore. With the establishment of the milestones to the 2050 targets (European Commission, 2011a), another communication (European Commission, 2011c) surveyed the different scenarios on achieving decarbonization, implicitly prioritizing the efficiency dimension of energy security. The same observation holds in the lead-up to the Fourth Energy Package with the presentation of the 2030 targets (European Commission, 2014b) and the specification of the contribution of energy efficiency to energy security and towards the achievement of the targets (European Commission, 2014c).

\subsection{Energy Security in the European Green Deal}

The broader Energy Union Package (European Commission, 2015) represents security of supply as one of its five major pillars alongside emissions reduction, internal market integration, energy efficiency, and research and innovation on low-carbon technologies (Ringel \& Knodt, 2018). The European Energy Security Strategy (European Commission, 2014a) and the Energy Union Package present solidarity in the pursuit and implementation of the Energy Union as a pathway towards energy security. They eventually framed the bulk of the additional elements of the Fourth Energy Package, known as the Clean Energy for all Europeans Package (European Commission, 2016). For the first time, the scope of the package expanded to incorporate practically all adjacent areas to energy policy and regulation. It incorporated measures on energy efficiency and renewable energy, the previous iterations of which were left outside the scope of the packages. Their integration speaks to the far more ambitious scope of the package and the prioritization of the binding climate policy objectives for 2030 under the new legislation. In addition, the approach 
previously reserved for risk-preparedness in the gas sector was extended to the electricity market by implementing measures for crisis identification and management. The latest expansion in the scope of energy security came in the Third Report on the State of the Energy Union (European Commission, 2017), which set the priorities of mitigating energy poverty and a socially fair energy transition as prerequisites to the enhancement of energy security. Energy poverty had already been introduced as an energy policy priority with the Fourth Energy Package but was now linked more explicitly with mitigating supply security risks through improvements in energy efficiency. The call for a socially fair transition was not elaborated in the Report but would receive much more attention in the EGD. Thus, while the main characteristic of security of supply remains at the core of the EU's approach to energy security, it has yet again been supplemented by additional elements.

The EGD (European Commission, 2019) represents a significant step in the historical trajectory of the convergence between climate and energy policy of the EU. Its overarching aim of creating a climate-neutral continent by 2050 is set as the main priority of the Commission for the period 2019-2024. There is neither a separate policy area dedicated to energy security nor a significant differentiation to the concept in relation to previous policy formulations. Nevertheless, various aspects of the broadened definition described above are included. The most overt specification of energy security as a policy priority is within the policy area of clean energy where the primary goal of the digitalization of the EU's energy systems is established in accordance with the three principles of: 1) energy efficiency with a growing basis on the use of renewable sources of energy, 2) the full integration, interconnection, and digitalization of the energy market, and 3 ) the security and affordability of energy supply. Therefore, the primary approach towards energy security-at least at the level of policy pronouncements-does not deviate from the traditional focus on supply. Yet, an examination of the key roadmap actions for the achievement of these policy objectives reveals a much more extensive characterization of the fundamental attributes of security and affordability that is interconnected with most of the other policy areas of the EGD. The "clean energy" priority area calls for the assessment of the final National Energy and Climate Plans, as well as the development of strategies for: 1) smart sector integration including a "renovation wave" initiative for the building sector, 2) increased offshore wind production, and 3) a clean and circular economy. Lastly, it calls for the evaluation and review of Regulation (EU) No 347/2013 on guidelines for trans-European energy infrastructure, known as the "TEN-E Regulation," with a new legislative proposal published in December of 2020 (European Commission, 2020). Overhauling the TEN-E Regulation may rectify an inherent contradiction between the existing policy objectives of the regulatory framework and the far-reaching goals of the EGD. While the Regulation includes elements such as the call for an increase in the use of renewable sources of energy, its approach to energy security remains firmly entrenched in its traditional formulation as any risk to energy supply. The emphasis on the interconnection of energy networks and infrastructure represents a direct mitigation of those risks (Schittekatte et al., 2020). However, projected future trends of relative stagnation in oil and gas demand (International Energy Agency, 2020, p. 30) are seemingly at odds with the prioritization of the gas and oil corridor categories. Even more importantly, they appear to be directly at odds with the goals of the EGD.

\section{Discussion}

Based on the above empirical analysis, the conceptual usage of energy security in the context of the elaboration of EU energy and climate policy is characterized by two tendencies. The first is a persistent emphasis on the traditional conception of energy security as security of energy supply, the maintenance of affordability, and the mitigation of associated risks. This is especially true where energy and climate policy objectives are considered in combination with external relations and the broader geopolitical and economic environment of the international system. Elements of this conceptualization are applied relatively narrowly to the regulation of the oil and gas markets prior to 2007 and to the electricity market thereafter. The second tendency establishes a widened conception of energy security that integrates additional pillars of energy and climate policy to bring the pursuit of energy security in line with the increasingly ambitious climate targets.

These two tendencies do not represent a mutually exclusive dichotomy; in other words, there is no clear and decisive chronological point where policy choices move starkly from one tendency to the other. The usage of energy security prior to the First Energy Package of 1996 remains firmly in the traditional approach. The supply continuity element has never been discarded and it remains a central tenet of EU energy policy. Its salience, however, has diminished over time in relation to additional characteristics such as efficiency and the use of renewable sources, as these elements increasingly tip the balance of priorities towards climate policy objectives with the EGD putting climate firmly at the center. These characteristics were integrated into the conceptual space of energy security as early as 2000 and there has been a constant widening ever since. Once a legislative framework was adopted that binds the EU to measurable climate policy targets, it could be argued that there can be no backtracking towards a reverse trend. Given the increasingly ambitious progression of the targets on greenhouse emissions reduction, share of renewables, and energy efficiency, it is difficult to conceive of an approach to energy security that divests itself of these characteristics. 
With respect to the second research question that concerns the evaluation of the EU's approach to turbulence, I note the following. In response to the first formulation of the questions-whether the EU is governing against or with turbulence through its energy security approach-it is evidently doing both. The reason is that the temporal characteristics of the two perspectives are different: Their incidence, the policy responses available, and the consequences of each occur in accordance with different time horizons. Therefore, when the EU prioritizes the traditional characteristics of energy security, it tends to be in response to crises, thus governing against turbulence in the short-term. On the other hand, the EU prioritizes the characteristics of the widened scope when it establishes long-term adaptations, whether that refers to long-term policy objectives such as the climate targets for 2050 or to long-term institutional change such as the transformation of decision-making structures towards the institutionalization of the Energy Union. As a result, we may conclude that in the conceptual evolution presented above, the long-term aspects inherent in governing with turbulence rather than against it, are becoming increasingly more significant. As discussed above, the example of the ongoing dilemma in EU-Russia relations (Goldthau \& Sitter, 2020) illustrates this conclusion. At various instances of crisis onset, we have witnessed a response through EU policy that seemed to reprioritize the traditional element of security of energy supply. But, at the same, the long-term strategic planning on achieving energy security veered in the direction of obviating the potential of future crisis onset through alternative means. Responses to external crises did not simply take the form of immediate crisis management but also forward-looking aims.

Lastly, is the EGD the logical continuation of a pathdependent process or does it aspire to fundamental change? Purely from the perspective of its contribution to the energy security conceptualization debate, we can observe elements of both. As described in the analysis above, characteristics of energy security such as energy poverty and a just transition have moved the usage of the term towards the social sphere of interaction. This is very much evident in the outlook for the EGD as well. It is clear-at least in terms of intent-that the EGD aspires towards fundamental change both in terms of institutional parameters in decision-making and in terms of adherence to social justice principles that have been absent up to this point. In that sense, the EGD can be characterized as a source of turbulence, the outcome of which will be determined by the multitude of actions in its projected roadmap. These include the implementation of a circular economy that significantly reduces demand for critical raw materials and accelerates the use of recycled materials and resources (Smol et al., 2020). In the industrial sector, general targets include minimizing the $20 \%$ share of EU emissions that come from industrial production, especially from sectors such as steel production and construction (Pianta \& Lucchese,
2020). This is combined with the overarching goals of the promotion of energy efficiency more broadly and the enhanced energy performance of buildings more specifically (Ringel et al., 2021). The same trend is observed in the inclusion of the transport policy area in the broader scope of the EGD, which has been traditionally considered adjacent to but effectively outside the boundaries of the EU climate and energy regulatory framework. While many of the details regarding the implementation of socially just priorities will be implemented in subsequent measures, the "Fit for 55" (European Commission, 2021) introduces the Social Climate Fund that represents the first practical measure towards the mitigation of energy poverty.

\section{Concluding Remarks and Avenues for Further Research}

Energy security remains a multifaceted concept that has grown in scope from a restricted perspective of supply security and affordability to a multiplicity of characteristics that integrate principles of the broader sustainability framework. This trajectory has been reflected in the energy and climate law and policy of the EU both in terms of overarching policy objectives and in terms of the utilization of energy security. At the core of the EGD is a multi-sectoral policy convergence, not only between the areas of energy and climate but also with associated areas such as transportation, industry, and construction. The comprehensiveness of this approach necessitates a widened conception of energy security, since its attainment must extend beyond the sufficiency of its supply to economic, technological, environmental, and sociocultural dimensions. In this sense, the extended conceptual scope of energy security illustrates that the pursuit of objectives in these other policy areas of the EGD contributes to the alleviation of risks associated with energy insecurity. It establishes alternative means of energy security, while it reduces the likelihood of crisis onset associated with exposure to the pressures of external geopolitical and economic relations in the international system.

Lastly, I introduce two avenues for further research emphasizing additional theoretical aspects of the framework. The first is the issue of energy governance. The empirical analysis illustrates that the pathway towards the policy integration of the Energy Union runs parallel to the conceptual evolution of energy security. The establishment of a supranational legal framework by EU member states, as envisioned by the Energy Union, illustrates the inability of traditional conceptions of energy security to capture the various challenges to state actors' unilateral action in the international system. As the legal framework matures, it will restrict the range of available policy options through the imposition of increasingly ambitious mandatory targets. For instance, it is impossible to analyze the evolution of policy objectives associated with energy efficiency without 
a simultaneous assessment of the evolution of measures on industrial emissions, air pollution, and the EU's emissions trading scheme, which Dupont (2020, p. 95) describes as "an example of EU policymaking advancing even under contestation." The concept of turbulence can inform our understanding of energy governance integration. This article describes the evolution of energy security in EU policy as both a response to crises and, more significantly, a policy adaptation towards longterm objectives. The evolution of institutional structures to govern this adaptation can be examined through the application of this framework.

The second avenue is the application of the framework to the examination of collective securitization in energy and climate policy. This approach characterizes the EU as a governance agent of collective securitization. According to Sperling and Webber (2019, p. 236), "the actor in question acts on behalf of other empowered actors who themselves may have individual securitizing imperatives." There have been multiple studies on the securitization of EU energy policy (Judge \& Maltby, 2017; Szulecki, 2020) and increasing interest in the securitization of climate policy. Dupont (2019) argues that convergence towards a unified position on climate change has enabled the collective securitization of climate policy and concludes that the potential of the EU as an agent of collective desecuritization is worth investigating. Hansen (2012, p. 541) suggests that desecuritization may involve "the combination of one issue moving out of security while another is simultaneously securitized." The coevolution of EU energy and climate policy priorities may constitute such a replacement.

\section{Acknowledgments}

I would like to thank the issue editors Claire Dupont and Diarmuid Torney, as well as all the other participants of the 2020 ECPR Joint Sessions Workshop on "Governing the EU's Climate and Energy Transition in Turbulent Times" for their valuable feedback, especially Tomas Maltby and Katja Biedenkopf who served as discussants on earlier drafts. I would also like to thank the anonymous peer reviewers for their constructive criticism and suggestions for improving the article.

\section{Conflict of Interests}

The author declares no conflict of interests.

\section{References}

Ang, B. W., Choong, W. L., \& Ng, T. S. (2015). Energy security: Definitions, dimensions and indexes. Renewable and Sustainable Energy Reviews, 42, 1077-1093. https://doi.org/10.1016/j.rser.2014.10.064

Ansell, C. (2016). Turbulence, adaptation, and change. In C. Ansell, J. Trondal, \& M. Øgård (Eds.), Governance in turbulent times (pp. 77-106). Oxford University
Press.

Ansell, C., \& Trondal, J. (2018). Governing turbulence: An organizational-institutional agenda. Perspectives on Public Management and Governance, 1(1), 43-57. https://doi.org/10.1093/ppmgov/gvx013

Ansell, C., Trondal, J., \& Øgård, M. (2016). Turbulent governance. In C. Ansell, J. Trondal, \& M. Øgård (Eds.), Governance in turbulent times (pp. 1-26). Oxford University Press.

Asia Pacific Energy Research Centre. (2007). A quest for energy security in the 21st century: Resources and constraints.

Bielecki, J. (2002). Energy security: Is the wolf at the door? The Quarterly Review of Economics and Finance, 42(2), 235-250. https://doi.org/10.1016/ S1062-9769(02)00137-0

Boin, A., Hart, P., Stern, E., \& Sundelius, B. (2005). The politics of crisis management: Public leadership under pressure. Cambridge University Press. https:// doi.org/10.1017/CBO9780511490880

Buzan, B., Wæver, O., \& De Wilde, J. (1998). Security: A new framework for analysis. Lynne Rienner.

Cherp, A., \& Jewell, J. (2014). The concept of energy security: Beyond the four As. Energy Policy, 75, 415-421. https://doi.org/10.1016/j.enpol.2014.09.005

Chester, L. (2010). Conceptualising energy security and making explicit its polysemic nature. Energy Policy, 38(2), 887-895. https://doi.org/10.1016/j.enpol. 2009.10.039

Christou, O., \& Adamides, C. (2013). Energy securitization and desecuritization. Security Dialogue, 44(5/6), 507-522. https://doi.org/10.1177/0967010 613499786

Ciuta, F. (2010). Conceptual notes on energy security: Total or banal security? Security Dialogue, 41(2), 123-144. https://doi.org/10.1177/096701061 0361596

de Jong, J., Glachant, J. M., Hafner, M., Ahner, N., \& Tagliapietra, S. (2012). A new EU gas security of supply architecture. European Energy Journal, 2, 32-40.

De Somer, S. (2012). The Europeanisation of the law on national independent regulatory authorities from a vertical and horizontal perspective. Review of European Administrative Law, 5(2), 93-130.

Dobbs, M., Gravey, V., \& Petetin, L. (2021). Driving the European Green Deal in turbulent times. Politics and Governance, 9(3), 316-326.

Dupont, C. (2019). The EU's collective securitisation of climate change. West European Politics, 42(2), 369-390. https://doi.org/10.1080/01402382.2018.1510199

Dupont, C. (2020). Defusing contested authority: EU energy efficiency policymaking. Journal of European Integration, 42(1), 95-110. https://doi.org/10.1080/ 07036337.2019.1708346

European Commission. (1995). White paper-An energy policy for the European Union (COM(95) 682 final).

European Commission. (1997). An overall view of energy policy and actions (COM(97) 167 final). 
European Commission. (2000a). The European Union's oil supply (COM(2000) 631).

European Commission. (2000b). Green paper-Towards a European strategy for the security of energy supply (COM(2000) 0769 final).

European Commission. (2002). Final report on the green paper "Towards a European strategy for the security of energy supply" (COM(2002) 321 final).

European Commission. (2003). Energy infrastructure and security of supply (COM(2003) 743 final).

European Commission. (2007). An energy policy for Europe (COM(2007) 1 final).

European Commission. (2008a). 2020 by 2020: Europe's climate change opportunity (COM(2008) 30 final).

European Commission. (2008b). An EU energy security and solidarity action plan (COM(2008) 781).

European Commission. (2010). Energy 2020-A strategy for competitive, sustainable and secure energy (COM(2010) 639 final).

European Commission. (2011a). A roadmap for moving to a competitive low carbon economy in 2050 (COM(2011) 112 final).

European Commission. (2011b). On security of energy supply and international cooperation-"The EU energy policy: Engaging with partners beyond our borders" (COM(2011) 539 final).

European Commission. (2011c). Energy roadmap 2050 (COM(2011) 0885 final).

European Commission. (2014a). European energy security strategy (COM(2014) 0330 final).

European Commission. (2014b). A policy framework for climate and energy in the period from 2020 to 2030 (COM(2014) 015 final).

European Commission. (2014c). Energy efficiency and its contribution to energy security and the 2030 framework for climate and energy policy (COM(2014) 520 final).

European Commission. (2014d). Progress towards completing the internal energy market (COM(2014) 634 final).

European Commission. (2015). State of the Energy Union 2015 (COM(2015) 572 final).

European Commission. (2016). Clean energy for all Europeans (COM(2016) 860 final).

European Commission. (2017). Third report on the state of the Energy Union (COM(2017) 688 final).

European Commission. (2019). The European Green Deal (COM(2019) 640 final).

European Commission. (2020). Proposal for a regulation of the European Parliament and of the Council on guidelines for trans-European energy infrastructure and repealing Regulation (EU) No. 347/2013 (COM(2020) 824 final).

European Commission. (2021). 'Fit for 55': Delivering the EU's 2030 climate target on the way to climate neutrality (COM(2021) 550 final).

Goldthau, A., \& Sitter, N. (2020). Power, authority and security: The EU's Russian gas dilemma. Journal of
European Integration, 42(1), 111-127. https://doi. org/10.1080/07036337.2019.1708341

Goldthau, A., \& Sovacool, B. K. (2012). The uniqueness of the energy security, justice, and governance problem. Energy Policy, 41, 232-40. https://doi.org/10.1016/ j.enpol.2011.10.042

Goldthau, A., \& Witte, J. M. (Eds.). (2010). Global energy governance: The new rules of the game. Brookings Institution Press.

Goldthau, A., \& Witte, J. M. (2015). Soft power with a hard edge: EU policy tools and energy security. Review of International Political Economy, 22, 941-965. https://doi.org/10.1080/09692290.2015. 1008547

Hansen, L. (2012). Reconstructing desecuritization: The normative-political in the Copenhagen School and directions for how to apply it. Review of International Studies, 38(3), 525-546. https://doi.org/ $10.1017 /$ S0260210511000581

Hawker, G., Bell, K., \& Gill, S. (2017). Electricity security in the European Union: The conflict between national capacity mechanisms and the single market. Energy Research \& Social Science, 24, 51-58. https:// doi.org/10.1016/j.erss.2016.12.009

Hughes, L. (2009). The four 'R's of energy security. Energy Policy, 37(6), 2459-2461. https://doi.org/10.1016/ j.enpol.2009.02.038

International Energy Agency. (2020). World energy outlook 2020. https://www.iea.org/reports/worldenergy-outlook-2020

International Energy Agency. (2021). Energy security. http://www.iea.org/topics/energysecurity

Judge, A., \& Maltby, T. (2017). European Energy Union? Caught between securitisation and 'riskification.' European Journal of International Security, 2(2), 179-202. https://doi.org/10.1017/eis.2017.3

Kemmler, A., \& Spreng, D. (2007). Energy indicators for tracking sustainability in developing countries. Energy Policy, 35(4), 2466-2480. https://doi.org/ 10.1016/j.enpol.2006.09.006

Kirchner, E., \& Berk, C. (2010). European energy security co-operation: Between amity and enmity. Journal of Common Market Studies, 48(4), 859-880. https://doi. org/10.1111/j.1468-5965.2010.02077.x

Labelle, M. C. (2017). Regulating for consumers? The Agency for Cooperation of Energy Regulators. In S. S. Andersen, A. Goldthau, \& N. Sitter (Eds.), Energy Union (pp. 147-164). Palgrave Macmillan.

Lesbirel, S. H. (2004). Diversification and energy security risks: The Japanese case. Japanese Journal of Political Science, 5(1), 1-22. https://doi.org/10.1017/ S146810990400129X

McGowan, F. (2011). Putting energy insecurity into historical context: European responses to the energy crises of the 1970s and 2000s. Geopolitics, 16(3), 486-511. https://doi.org/10.1080/14650045.2011. 520857

Moore, S. (2017). Evaluating the energy security of elec- 
tricity interdependence: Perspectives from Morocco. Energy Research \& Social Science, 24, 21-29. https:// doi.org/10.1016/j.erss.2016.12.008

Narula, K. (2019). The maritime dimension of sustainable energy security. Springer. https://doi.org/10.1007/ 978-981-13-1589-3

Natorski, M., \& Herranz-Surralles, A. (2008). Securitizing moves to nowhere? The framing of the European Union's energy policy. Journal of Contemporary European Research, 2(2), 70-89.

Olsen, J. P. (2010). Governing through institution building: Institutional theory and recent European experiments in democratic organization. Oxford University Press. https://doi.org/10.1093/acprof:oso/ 9780199593934.001.0001

Pasqualetti, M. J., \& Sovacool, B. K. (2012). The importance of scale to energy security. Journal of Integrative Environmental Sciences, 9(3), 167-180. https:// doi.org/10.1080/1943815X.2012.691520

Pianta, M., \& Lucchese, M. (2020). Rethinking the European Green Deal: An industrial policy for a just transition in Europe. Review of Radical Political Economics, 52(4), 633-641.

Pierson, P. (2000). Increasing returns, path dependence, and the study of politics. American Political Science Review, 94(2), 251-267.

Radovanović, M., Filipović, S., \& Pavlović, D. (2017). Energy security measurement: A sustainable approach. Renewable and Sustainable Energy Reviews, 68, 1020-1032. https://doi.org/10.1016/ j.rser.2016.02.010

Ringel, M., Bruch, N., \& Knodt, M. (2021). Is clean energy contested? Exploring which issues matter to stakeholders in the European Green Deal. Energy Research \& Social Science, 77, Article 102083.

Ringel, M., \& Knodt, M. (2018). The governance of the European Energy Union: Efficiency, effectiveness and acceptance of the Winter Package 2016. Energy Policy, 112, 209-220.

Schittekatte, T., Pototschnig, A., Meeus, L., Jamasb, T., \& Llorca, M. (2020). Making the TEN-E regulation compatible with the Green Deal: Eligibility, selection, and cost allocation for PCls (Policy Brief 2020/27). European University Institute. https://doi.org/10.2870/ 304592

Smol, M., Marcinek, P., Duda, J., \& Szołdrowska, D. (2020). Importance of sustainable mineral resource management in implementing the circular economy (CE) model and the European Green Deal strategy. Resources, 9(5), Article 55.

Sperling, J., \& Webber, M. (2019). The European Union: Security governance and collective securitisation. West European Politics, 42(2), 228-260. https://doi. org/10.1080/01402382.2018.1510193

Szulecki, K. (2020). Securitization and state encroachment on the energy sector: Politics of exception in Poland's energy governance. Energy Policy, 136, Article 111066. https://doi.org/10.1016/j.enpol. 2019.111066

Thelen, K. (1999). Historical institutionalism in comparative politics. Annual Review of Political Science, 2(1), 369-404. https://doi.org/10.1146/annurev.polisci.2. 1.369

Vivoda, V. (2010). Evaluating energy security in the Asia-Pacific region: A novel methodological approach. Energy Policy, 38(9), 5258-5263. https://doi.org/ 10.1016/j.enpol.2010.05.028

von Hippel, D., Suzuki, T., Williams, J. H., Savage, T., \& Hayes, P. (2011). Energy security and sustainability in Northeast Asia. Energy Policy, 39(11), 6719-6730. https://doi.org/10.1016/j.enpol.2009.07.001

Winzer, C. (2012). Conceptualizing energy security. Energy Policy, 46, 36-48. https://doi.org/10.1016/ j.enpol.2012.02.067

\section{About the Author}

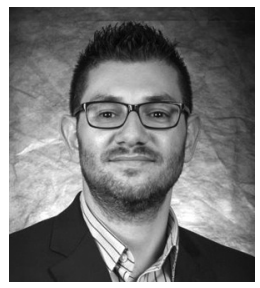

Odysseas Christou (PhD) is assistant professor in Government, International Law, and International Relations at the School of Law of the University of Nicosia. His research interests and most recent publications are focused on EU energy, environmental, and climate law and policy, as well as security relations and securitization processes in the Eastern Mediterranean, particularly with respect to energy-related regional developments. 